\title{
Viljelijäväestön tulojen ja tulonmuodostuksen muutos
}

\author{
Maija Puurunen $^{1)}$, Risto A. Seppälä2), \\ ${ }^{1)}$ Etelä-Savon TE-keskus PL 16450100 Mikkeli ,maija.puurunen@te-keskus.fi \\ ${ }^{2)}$ MTT Taloustutkimus Luutnantintie 1300410 Helsinki, risto.a.seppala@mtt.fi
}

Viljelijäväestön tulot muodostuvat monesta eri tulolähteestä. Kuitenkin osalla tiloista maatalous ja sen ohessa metsätalous ovat edelleen pääasiallisimmat tulolähteet. Varsinkin kotieläintalouteen vahvasti investoineilla suurimmilla tiloilla maataloudesta pyritään saamaan viljelijäperheen koko toimeentulo. Yhä suuremmalla osalla tiloista tulot hankitaan tilan ulkopuolelta palkka- ja yrittäjätuloina ja myös pääomasijoituksista saatavina tuloina. Osalla viljelijäperheistä lähes koko tulonmuodostus on sidoksissa maatalouden tukiratkaisuihin ja hinta- ja kustannuskehitykseen, kun taas osalla viljelijäperheistä maatalouden tuloilla on varsin vähäinen merkitys.

Tutkimuksessa viljelijäperheen tuloja on tarkasteltu maatilatalouden verotuksen tietoihin perustuvan Tilastokeskuksen maatilatalouden yritys- ja tulotilaston (MYTT) luonnollisten henkilöiden tilaaineiston ja siihen liitetyn henkilöverotuksen aineiston sekä Tiken tilastoimien maatilojen rakennetietojen avulla. MYTT:n viimeisimmät tulokset ovat vuodelta 2004, jolloin luonnollisten henkilöiden tiloja koskeva otos oli runsas 6700 tilaa, mikä edustaa 68900 tilan perusjoukkoa.

Yli 75 \% maatilataloudesta tuloistaan saavien päätoimisimpien tilojen osuus kaikista luonnollisten henkilöiden tiloista on vähentynyt vuosina 1995-2004 noin 38 \%:sta 30 \%:iin. Vastaavasti osaaikaisimpien tilojen osuus kaikista tiloista on kasvanut. Päätoimisimpien tilojen koko peltoalalla mitattuna on kasvanut vuosina 1995-2004 yli puolitoistakertaiseksi, mutta maataloustulo on kasvanut reaalisesti vain $12 \%$ (vuosimuutosten summa). Maataloustulon osuus viljelijäpuolisoiden kokonaistuloista oli näillä tiloilla vuonna 2004 keskimäärin $82 \%$, metsätaloustulojen osuus 9 \% ja muiden tulojen osuus $9 \%$. Päätoimitilojen kokonaistulot ovat kasvaneet vuosina 1995-2004 reaalisesti yhteensä $12 \%$ ja ne olivat vuonna 2004 nimellisesti $36600 € /$ tila ja $22300 € /$ henkilö. Myös tilaryhmässä, jossa maatilatalouden tulo-osuus on 50-75\%, maatalouden tulokehitys on ollut hyvin samantyyppinen kuin päätoimisimmilla tiloilla.

Osa-aikaisimmissa kahdessa tilaryhmässä, joissa maa- ja metsätalouden tulojen osuus viljelijäpuolisoiden kokonaistuloista on alle $25 \%$ tai 25-50 \%, maataloustulon osuus viljelijäpuolisoiden kokonaistuloista oli vain $6 \%$ ja seuraavaksi osa-aikaisimmassa tilaryhmässä $30 \%$ kokonaistuloista. Palkkatuloilla on näillä tiloilla suuri merkitys, sillä ensin mainitussa osa-aikatilojen ryhmässä ne muodostivat 56 \% ja seuraavassa noin 37 \% kokonaistuloista. Vuosina 1995-2004 kokonaistulot ovat kasvaneet osa-aikaisimmassa neljänneksessä tiloista yhteensä 28 \%, mikä on keskimäärin 3,1 \% vuodessa ja seuraavaksi osa-aikaisimmassa tilaryhmässä yhteensä $19 \%$ eli 2,1 \% vuodessa.

Koska maatalouden tulokehitys on ollut muita aloja heikompi, päätoimisimmat voimakkaasti maatalouteen investoineet viljelijät ovat vaarassa jäädä paitsioon yhteiskunnan muusta tulokehityksestä. Sitä vastoin osa-aikaisimmilla tiloilla viljelijä ja puoliso pääsevät osallisiksi muiden alojen positiiviseen tulokehitykseen. Maatalouden tulojen merkityksen vähenemisen myötä monet viljelijät ja vielä useammin heidän puolisonsa mieltävät itsensä työtehtäviensä ja tulojensa mukaan pikemminkin maaseudulla asuviksi eri toimialojen palkansaajiksi, toimihenkilöiksi tai muiden alojen yrittäjiksi kuin maatalouden harjoittajiksi.

Asiasanat: tulot, tulotyypit, rakennemuutos. 


\section{Johdanto}

Maa- ja puutarhataloussektorin maataloustulo on laskenut merkittävästi Suomen EU-jäsenyyden alusta lähtien (Niemi 2007). Jos vuoden 1994 maataloustuloa kuvataan suhdeluvulla 100, maataloustulo laski vuoteen 1998 mennessä 60 - 65 yksikköön eli kolmanneksella. Sittemmin maataloustulo nousi vuoteen 2002 mennessä nimellisesti 80 \%:iin ja reaalisesti 70 \%:iin vuoden 1994 tasosta, mutta laski jälleen vuoteen 2006 mennessä niin, että reaalinen maataloustulo oli enää noin 55 \% vuoden 1994 tasosta. Samaan aikaan aktiivitilojen määrä on alentunut kolmanneksella. Siten tilaa kohti laskettu reaalinen maataloustulo ei ole kasvanut rakennekehityksestä huolimatta

Useilla tiloilla kokonaistulo koostuu useista tulonlähteistä. Viljelijäväestön kokonaistulojen on aiemmissa tutkimuksissa määritelty koostuvan maa- ja metsätaloudesta saatavien tulojen lisäksi muusta yritystoiminnasta saatavista tuloista, palkkatuloista, omaisuustuloista ja tulonsiirroista (Puurunen 1987, Puurunen 1990, Väre 2000). Näiden eri tulonlähteiden merkitys kokonaistulon muodostuksessa riippuu toisaalta tulonsaajan toiminnan keskittymisestä tiettyyn tulonlähteeseen ja toisaalta tulonlähteestä saatavan tulon kehityksestä suhteessa muihin tulolähteisiin. Jo 1980-luvun loppupuolelta lähtien on tulonsiirtojen, muun yritystoiminnan, omaisuustulojen ja etenkin palkkatulojen osuus tilan kokonaistuloista keskimäärin kasvanut. Tästä huolimatta noin kolmasosalla tiloista maatalous ja sen ohessa metsätalous ovat edelleen pääasialliset tulolähteet. Varsinkin kotieläintalouteen vahvasti investoineilla suurimmilla tiloilla maataloudesta pyritään saamaan viljelijäperheen koko toimeentulo, sillä kotieläintalous työvoimaa ympärivuotisesti päivittäin sitovana tuotantomuotona rajoittaa muiden tulonlähteiden hyödyntämismahdollisuuksia.

Tässä tutkimuksessa tarkastellaan viljelijäpuolisoiden kokonaistulojen muodostumista eri tulonlähteistä sekä tulokehitystä vuosina 1995 - 2004. Lisäksi selvitetään, miten tulot ovat muuttuneet maatalouden tulo-osuuden mukaisissa tilaluokissa.

\section{Aineisto ja menetelmät}

Maatilojen tulojen tarkastelu pohjautuu luonnollisten henkilöiden viljelemien tilojen veroilmoituksien tulotietoihin ja näiden tilojen rakennetietoihin kuten Puurusen ja Väreen tutkimuksissa (Puurunen 1987, Puurunen 1990, Väre 2000). Luonnollisten henkilöiden tilajoukko kattaa noin 90 \% kaikista aktiivitiloista. Loput n. 10 \% tiloista ovat perheyhtiöitä, -yhtymiä ja perikuntia.

Tarkasteluissa käytetty aineisto perustuu Tilastokeskuksen Maatilatalouden yritys- ja tulotilaston (MYTT) tietoihin. Tilastokeskus kerää tiedot vuosittain maatilatalouden tuloverolain mukaan verotettujen, vähintään kahden viljellyn peltohehtaarin kokoisilta maatiloilta. Vuoden 2003 verotustietoihin asti poimittiin kaikkien tilojen joukosta kiintiöidyllä otannalla noin 9000 maatilan edustava otosjoukko, jolta verotustiedot kerättiin. Otokseen valituille tiloille lähetettiin myös kysely, jolla veroilmoituksissa annettuja tietoja täydennettiin (Tilastokeskus 2006). Verovuodesta 2004 alkaen tilastokeskus on saanut verotustiedot kaikilta maatiloilta suoraan verohallinnosta. Otannalla muodostettua tilajoukkoa käytetään kuitenkin edelleen tarkennustietojen keruuta varten (Tilastokeskus 2007).

Aineistoon kuuluvien tilojen viljelijän ja hänen puolisonsa palkka- ym. tulotiedot on liitetty aineistoon Tilastokeskuksen Maatilatalouden tulo- ja verotilaston aineistosta, joka sisältää henkilöverotuksen tiedot 1. verolomakkeelta. Tilojen pinta-ala- ja eläinmäärätiedot on poimittu MMM:n Tietopalvelukeskuksen (Tike) IACS -rekisterin tiedoista.

Maatilojen tulojen tarkastelussa on tässä yhteydessä käytetty maatalouden tuloksesta nimikettä maataloustulo, joka määritelmänsä mukaan kuvaa viljelijäperheen maataloustyölle ja maatalouteen sijoitetulle omalle pääomalle saatua korvausta (MTT Taloustutkimus 2007). Maatalouden tulos on laskettu verotustiedoissa ilmoitettujen maatalouden tulojen ja menojen erotuksena, johon on lisätty korjauseränä kirjanpitotilojen tulosten perusteella arvioitu yksityistaloudessa käytettyjen tuotteiden arvo (ns. kotitarvetuotto) (Väre 2000). Kotitarvetuoton korjauserää lukuun ottamatta tulos vastaa Tilastokeskuksen MYTT -tilaston tunnuslukua ”Tulos maataloudesta” (Tilastokeskus 2006). Metsätalouden tulot sisältävät metsätalouden puhtaan tulon ja/tai metsätalouden pääomatulon, valitun metsätalouden verotusmuodon mukaan. Muut yrittäjätulot koostuvat maa- ja metsätalouden verotuksen ulkopuolelle jäävän yritystoiminnan pääomatulo- ja ansiotulo-osuuksista. Palkkatulot sisältävät palkan ja luontaisedut. Omaisuustuloihin on luettu vuokratulot, osingot, yms. ja saatuihin tulonsiirtoihin eläkkeet ja päivärahat. Välittömiä veroja ei ole vähennetty kokonaistuloista (Väre 2000). 
Verotustietojen pohjalta voidaan kattavasti tarkastella viljelijöiden tulojen muodostusta, koska verotuksen mukaiset tulotiedot kerätään kaikilta maatiloilta. Tarkkaan liiketuloskäsitteistön mukaiseen tulos- ja tuotantokustannuslaskentaan verotusaineiston tiedot eivät kuitenkaan ole riittävät.

\section{Tulokset}

Viljelijän ja puolison yhteiset tulot (tulot tilaa kohden) luonnollisten henkilöiden maatiloilla keskimäärin vuosina 1986-2004 esitetään tulolajeittain kuviossa 1. Luvut on muutettu kuluttajahintaindeksillä vuoden 2006 hintatasoon. Näiden keskimääräisten tulosten mukaan maataloustulo ei ole reaalisesti juurikaan kasvanut vuosina 1990-2004. 1990-luvun loppupuolella maataloustulo laski ennen kääntymistään hyvin lievään nousuun 2000-luvulla. Keskimääräiset kokonaistulot sen sijaan ovat nousseet lähes koko ajan etenkin palkka- ja omaisuustulojen kasvun ansiosta. Muiden tulojen kasvun myötä maataloustulon osuus viljelijöiden kokonaistuloista on laskenut. Vuonna 2004 keskimäärin 36,3 \% viljelijöiden kokonaistuloista muodostui maataloustulosta, kun vastaava osuus oli vuonna 1986 vielä 49,6 \%. 1986-1997 tapahtuneet heilahdukset kokonaistuloissa ovat pääasiassa peräisin maataloustulon vaihteluista hyvien $(1990)$ ja huonojen $(1987,1992)$ satovuosien ja vuonna 1995 maksettujen varastokorvauksien takia (Väre 2000).

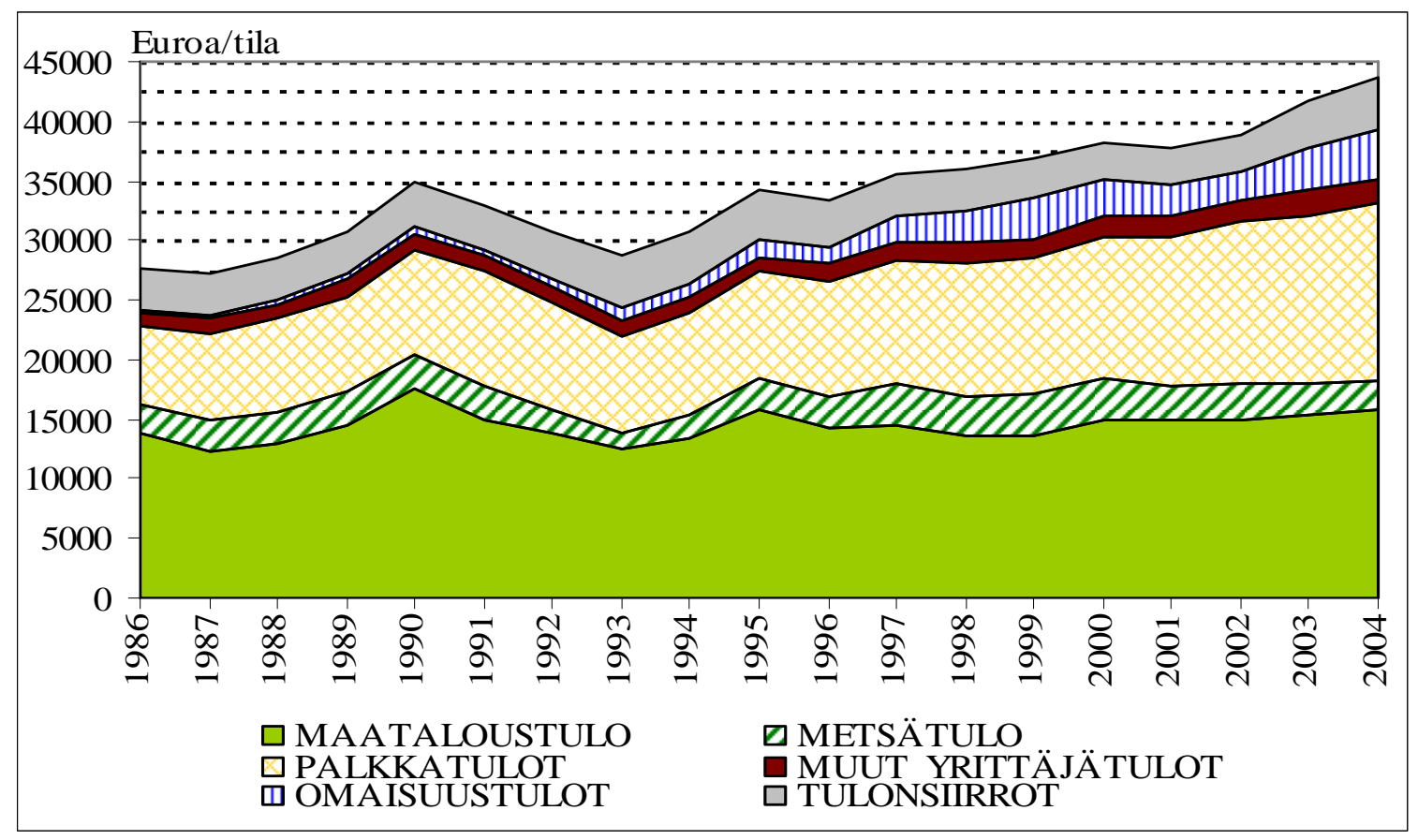

Kuvio 1. Viljelijäpuolisoiden kokonaistulojen muodostuminen keskimäärin luonnollisten henkilöiden tiloilla (Eur/tila) vuosina 1986-2004 (tiedot vuoden 2006 hintatasossa).

Kun tarkasteltavana oleva tilajoukko jaetaan ryhmiin maa- ja metsätalouden kokonaistuloosuuden mukaan, voidaan tulokehitystä tarkastella tulojen perusteella pää- ja sivutoimisiksi luokitelluilta viljelijöiltä/viljelijäpuolisoilta (Peltola 1999).

Ryhmittelyn mukaiset keskimääräiset tulot ja niiden kehitys vuosina 1995-2004 esitetään kuviossa 2 vuoden 2006 hintatasossa. Tulosten mukaan päätoimisimmassa ryhmässä, jossa kokonaistuloista yli $75 \%$ tulee maatilataloudesta, maataloustulo ja siten myös kokonaistulot laskivat 2000-luvun alkuun asti. Tällöin tulokehityksessä tapahtui käänne ja näiden tilojen maataloustulot kasvoivat reaalisesti n. 12 \% vuoteen 2004 mennessä. Päätoimisten tilojen ryhmän muissa tuloissa ei juuri ole tapahtunut muutoksia, joten kokonaistulojen kehitys on seurannut maataloustulon kehitystä. Maataloustulojen osuus kokonaistulosta oli tässä ryhmässä 82 \% vuonna 2004.

Kuviosta 2 nähdään, että mitä pienempi on maataloustulon osuus tilaryhmän kokonaistuloista, sitä vähemmän maataloustulo nousi vuosina 2000-2004. Tiloilla, joilla maatilataloudesta saatavat tulot ovat 50-75 \% kokonaistuloista maataloustulossa on varsinaisesti havaittavissa kasvua vain parina vii- 
meisenä tarkasteluvuotena 2003 ja 2004. Aiempina vuosina tapahtunut kokonaistulojen kasvu on muodostunut lähinnä muiden kuin maataloustulojen kasvusta.

Tilaryhmässä, jossa maa- ja metsätalouden tulojen osuus viljelijäpuolisoiden kokonaistuloista on 25-50 \%, kokonaistulot ovat kasvaneet yhteensä 19 \% eli 2,1 \% vuodessa lähinnä palkka- ja pääomatulojen kasvun ansiosta. Palkka- ja pääomatulojen osuus on vuonna 2004 yhteensä 46 \% ja maataloustulon osuus $30 \%$ kokonaistuloista.

Tulorakenteen mukaan osa-aikaisimmassa tilaryhmässä, jossa maatilataloudesta tulee alle $25 \%$ kokonaistuloista, ovat kokonaistulot kasvaneet tarkasteluajanjaksolla vuosien 2001 ja 2002 notkahdusta lukuun ottamatta. Yhteensä kasvu on ollut n. $28 \%$. Tulojen kasvu on etupäässä seurausta palkka- ja pääomatulojen kasvusta. Maataloustulojen muutos on lähinnä ollut vuosittaista vaihtelua matalan, n. 6 \% kokonaistuloista vuonna 2004, tason ympärillä. Palkkatulojen osuus viljelijäpuolisoiden kokonaistuloista oli tässä päätoimisuusluokassa 56 \% vuonna 2004.

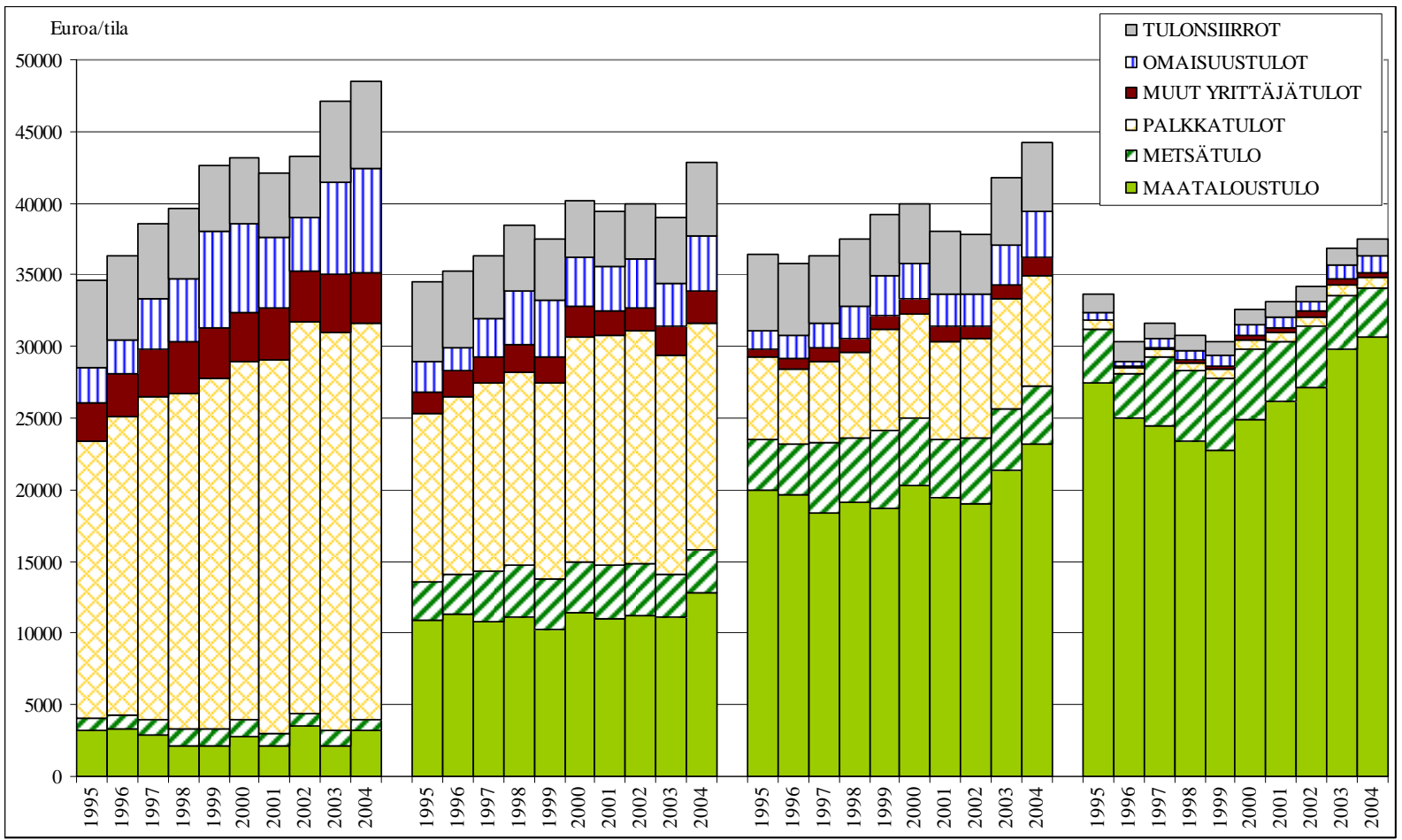

Kuvio 2. Viljelijäpariskuntien kokonaistulot ja tulojen muodostuminen 1995-2004 Eur/tila, vuoden 2006 hintatasossa maataloustulon kokonaistulo-osuuden mukaan ryhmiteltynä.

Kuviossa 3 on esitetty tilojen määrä eri päätoimisuusluokissa tutkimusaineiston perusteella. Kokonaistilamäärä on vuodesta 1997 vuoteen 2004 laskenut miltei 16 \%. Päätoimisuusryhmien sisällä suurin muutos on kohdistunut päätoimitiloihin, joiden määrä on vähentynyt $30 \%$. Tulo-osuusluokissa 25-49 \% ja 50-75 \% lasku on ollut vähäisempää (14 \% ja 23 \%). Osa-aikaisimmassa luokassa tilojen määrä on vaihdellut ja 2000-luvulla tilaryhmän koko on kasvanut. Ilmiötä selittää ainakin osittain maatilojen muun yritystoiminnan yleistyminen (Rantamäki-Lahtinen ym. 2006) ja maatalouden ulkopuolisten tulolähteiden suhteellisesti parempi tulokehitys. Molemmat tekijät ovat siirtäneet tiloja päätoimisemmista tilaryhmistä osa-aikaisempiin tilaryhmiin. 


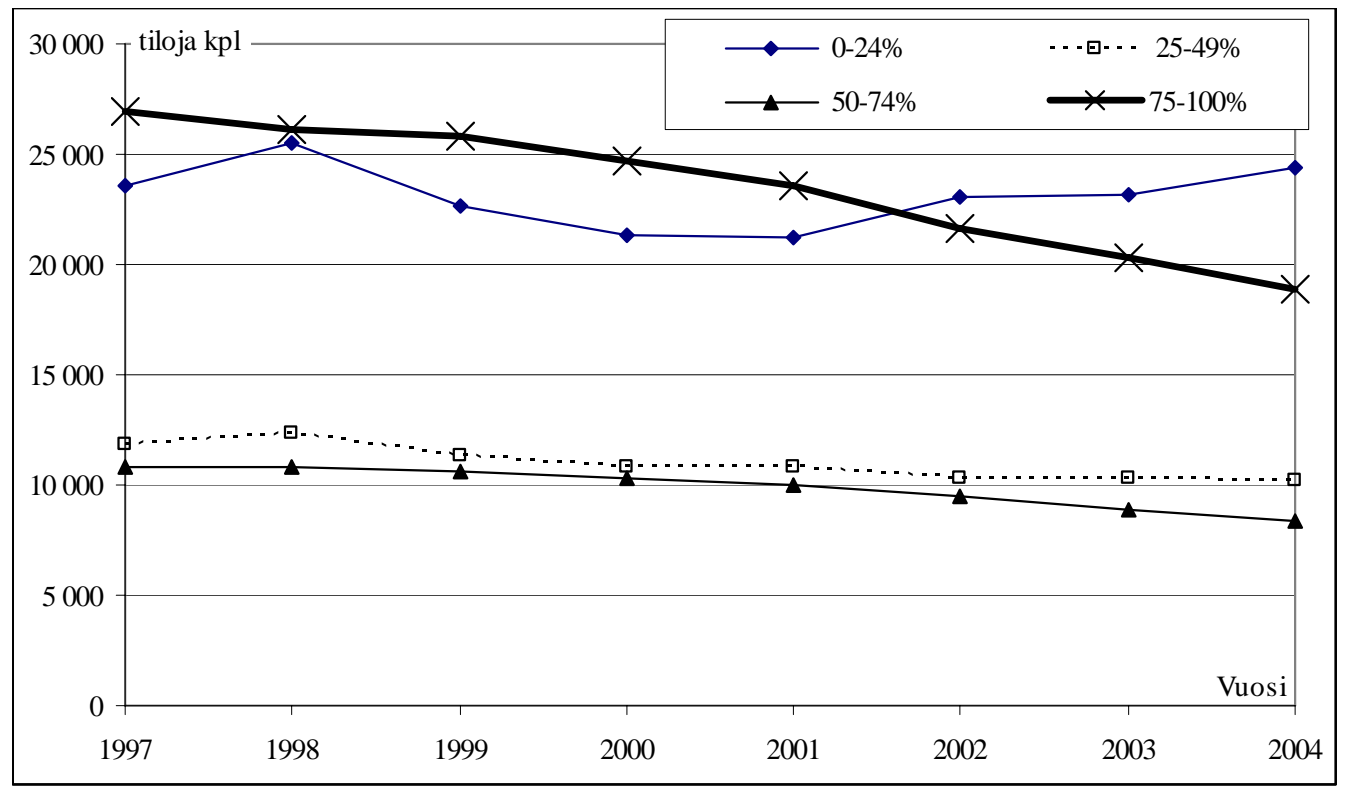

Kuvio 3. Tilamäärien kehitys vuosina 1997-2004 eri päätoimisuusluokissa.

Kuviossa 4 esitetään tilakoon kehitys päätoimisuusluokissa vuosina 1995-2004. Tulo-osuusluokan keskimääräisellä eläinmäärällä mitattuna alle $25 \%$ tuloistaan maataloudesta saavien tilojen ryhmässä ei juuri ole tapahtunut muutoksia. 25-50 \% ryhmässä vuosittainen vaihtelu on ollut suurempaa kuin edellisessä ryhmässä, mutta selvää eläinmäärän nousua/laskua ei tässäkään ryhmässä voi sanoa tapahtuneen tarkasteluajanjaksolla. Kuitenkin tilaryhmissä, joissa maatalouden tulo-osuus on yli 50 \% kokonaistuloista, keskimääräinen eläinmäärä on kasvanut. Kaikkein päätoimisimmassa tilaryhmässä eläinmäärä on kasvanut vuosien 1995 ja 2004 välillä 26 nautayksiköstä (ny) 35 nautayksikköön. 50-75 \% ryhmässä nousu on ollut heikompaa; noin 20 nautayksiköstä 25 nautayksikköön.
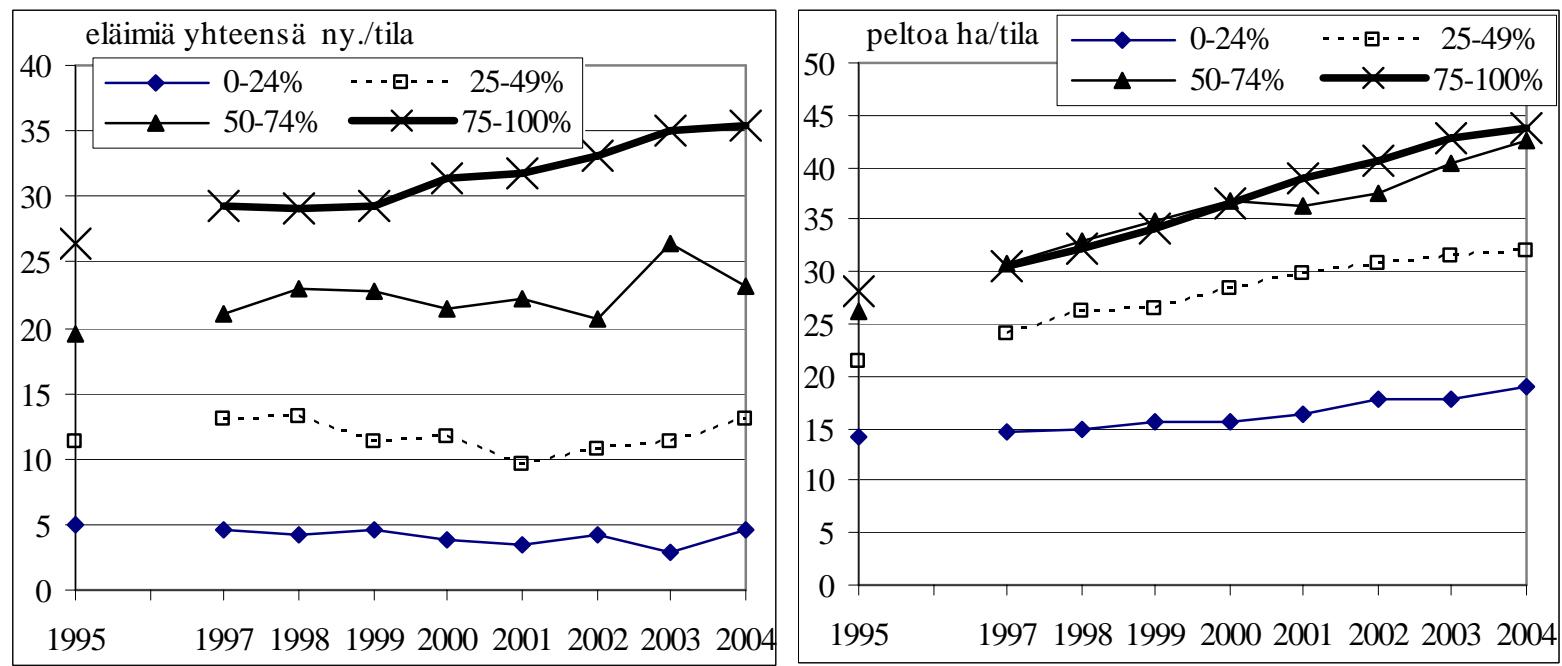

Kuvio 4. Tilakoon kehitys päätoimisuusryhmittäin vuosina 1995 ja 1997-2004 ,vasemmalla eläinmäärät ja oikealla peltohehtaarit tilaa kohden.

Peltoalalla mitattuna keskimääräinen tilakoko on kasvanut kaikissa päätoimisuusluokissa (kuvio 4). Kasvu on ollut sitä nopeampaa, mitä päätoimisemmasta tilajoukosta on kyse. Pienimillään kasvu on ollut tulo-osuusluokassa 0-25 \%. Vuonna 1995 tämän tilaryhmän tiloilla oli peltoa keskimäärin 14 ha ja vuonna 2004 keskimäärin 19 ha. Tulo-osuusluokassa 25-50 \% ala on vastaavasti noussut 21:stä 
32 hehtaariin. Kahdessa päätoimisimmassa tilaryhmässä peltoala ja sen kehitys ovat olleet miltei samoja, sillä pinta-ala on kasvanut noin 27 hehtaarista 43 hehtaariin.

Tilaryhmien keskitilakoossa tapahtuneet muutokset voidaan jakaa yksittäisten tilojen todellisesta muutoksesta ja ryhmien pienempien tilojen tuotannon lopettamisesta johtuvaan keskiarvon nousuun (Pyykkönen 1999, Väre 2000). Tulosten perusteella päätoimisilla tiloilla investointien tai pienempien tilojen lopettamisen kautta tapahtunut ryhmän keskimääräisen tilakoon ja tulotason kasvu ei kuitenkaan ole vastannut osa-aikaisemmissa tilaryhmissä muiden kuin maataloustulojen kasvun kautta tapahtunutta tulokehitystä.

\section{Johtopäätökset}

Maatalouden tuloista riippuvaisimpien päätoimisten maatilojen kokonaistulot ovat kasvaneet hitaammin kuin muiden maataloutta harjoittavien tilojen kokonaistulot. Vastaavasti kaikissa maatalouden tulo-osuuden mukaisissa tilaluokissa maataloustulo on kasvanut vain hieman tai ei lainkaan vuodesta 1995 vuoteen 2004. Siten tilakoon kasvun tuoma kokoetu ei ole realisoitunut merkittävästi suurempana reaalisena maataloustulona. Koska maatalouden tulokehitys on ollut muita aloja heikompaa, päätoimisimmat voimakkaasti maatalouteen investoineet viljelijät ovat vaarassa jäädä jälkeen yhteiskunnan muusta tulokehityksestä. Maatalouden, erityisesti kotieläintalouden, harjoittamisen houkuttelevuus ammattina kuitenkin edellyttäisi paitsi kohtuullista tulokehitystä myös riittävää kannattavuutta, joka mahdollistaisi tuotannon kehittämisen edellytyksenä olevan hallitun riskinoton. Sitä vastoin osaaikaisimmilla tiloilla viljelijä ja puoliso pääsevät osallisiksi muiden alojen positiivisesta tulokehityksestä, joten tässä tilaryhmässä kokonaistulo on kehittynyt suotuisimmin. Kuitenkaan maataloustulo ei osa-aikaisemmilla tiloilla ole kasvanut reaalisesti lainkaan. Vähäisestä tulonmuodostuksesta johtuen näillä tiloilla tuskin usein myöskään panostetaan maatalouden kehittämiseen.

Tuloksia tarkasteltaessa on huomattava, että esimerkiksi voimakkaasti tuotantoaan kasvattaneilla tiloilla maataloustulo voi tuotantoa käynnistettäessä jäädä hyvin alhaiseksi, jolloin työn- ja pääomankäyttönsä perusteella päätoimisesti maataloutta harjoittava tila voi tulla luokitelluksi osaaikaiseksi tai ainakin sen kokonaistulo jää päätoimisena tämän vuoksi alhaiseksi. Ajan yli tapahtuviin muutoksiin saataisiinkin lisävalaistusta, mikäli tulotason kehitystä voitaisiin tarkastella paneeliaineiston avulla.

\section{Kirjallisuus}

MTT Taloustutkimus. 2007. Yrityksen tulosta kuvaavat tunnusluvut. Verkkojulkaisu. https://portal.mtt.fi/portal/page/portal/taloustohtori/kannattavuuskirjanpito/taustatiedot/Tunnusluvut ～(viitattu 14.11.2007).

Peltola, A. 1999. Päätoimisuuskriteerit suomalaisilla maatiloilla. Maatalouden taloudellisen tutkimuslaitoksen Selvityksiä 14/99. $70 \mathrm{~s}$.

Puurunen, M. 1987. Viljelijäväestön tulojen vertaaminen muiden väestöryhmien tuloihin. Maatalouden taloudellisen tutkimuslaitoksen tiedonantoja $134.171 \mathrm{~s}$.

Puurunen, M. 1990. A Comparative Study on Farmers' Income. Maatalouden taloudellisen tutkimuslaitoksen julkaisuja 62. $114 \mathrm{~s}$.

Rantamäki-Lahtinen, L. \& Mustalahti, I. 2006. Maatilojen muu yritystoiminta 2005, Maa- ja metsätalousministeriön tietopalvelukeskus TIKE. 37 s.

Pyykkönen, P. 1999. Maatalouden rakennemuutoksen vaikutus tulokehitykseen EU-jäsenyyden alkuvuosina. Pellervon taloudellisen tutkimuslaitoksen raportteja 166. 39 s.

Niemi, J. 2007. Teoksessa Niemi, J. \& Ahlstedt, J. (toim.) Suomen maatalous ja maaseutuelinkeinot 2007. MTT Taloustutkimus. $96 \mathrm{~s}$.

Tilastokeskus. 2006. Maatilatalouden yritys- ja tulotilasto 2003. Suomen virallinen tilasto. Maa-, metsä-, ja kalatalous 2006. $67 \mathrm{~s}$. 
Tilastokeskus. 2007. Maatilatalouden yritys- ja tulotilaston verkkojulkaisu. http://www.tilastokeskus.fi/til/myt/2004/myt_2004_2007-03-22_tie_001.html (viitattu 14.11.2007)

Väre, M. 2000. Viljelijöiden tulotasovertailu. Maatalouden taloudellisen tutkimuslaitoksen tutkimuksia 242. 168 s. 